\title{
Cranial Gravitational (Falling) Bullet Injuries: Point of View
}

Sir,

Cranial gravitational bullet injuries and human and material losses apply to those falling bullets and their effect when they struck the cranium of human being and their consequence and material loss. Our aims were to study the importance of craniocerebral falling-bullet injuries, the clinical and computed tomography scan criteria, events that are associated with bullet firing, treatment options, and outcome of these injuries. Reviewing literatures: we search all the available literature from 1990 to October 2017 in PubMed, Google Scholar, and ResearchGate with the following key words: gravitational bullets injury, tangential wound, penetrating wound, ricochet, careening, and falling-bullet hear injury. The wounds caused by gravitational projectiles are a relevant problem in many countries of the world. The problem caused by this type of elements must be addressed from the prevention.

Falling bullets or gravitational bullets are the ones that move under the effect of the gravity force after the muzzle force diminished. Falling bullets are seen in aerial firing or what is classified by the international disease classification system as celebratory firing ${ }^{[1]}$ during which bullets are shot into the sky to celebrate a happy event or to express anger in some countries of the middle east, north Africa, south America, and middle of Asia. Marriage ceremony is the most common event where aerial firing are done and consequent injury sustained. ${ }^{[2]}$ Falling bullets are also seen in the USA and reported as incidental to street violence in $59.2 \%$ of the shooting events while due to celebratory firing in $4.6 \%{ }^{[3]}$ Another event where falling bullets are seen is aerial shooting during riot and mob control noted in the setting of conflict zones. ${ }^{[4]}$

After upward shooting, the bullets will move under the effect of explosive acceleration first; then, because of the gravity, their velocities will decelerate till reaching zero, and at this point, the movement of the bullets will change to downward and their velocities will be accelerated by the effect of the gravity until the air resistance drag equalizes the effect of the gravity so the bullets will reach the terminal constant velocity. ${ }^{[5]}$

The terminal velocity of a bullet depends on multiple factors. One of them is the bullet composition. Most of the bullets are made of lead due to having a high specific gravity and more weight per volume. This will make the lead bullets have less air drag per mass when falling down which will make the terminal velocity higher ${ }^{[6]}$ Another factor that affects the terminal velocity is the angle of firing. If the angle was between $20^{\circ}$ and $45^{\circ}$ or even more acute, the bullet will travel further with higher speed over terminal velocity ${ }^{[5]}$ while the vertical firing will end with lower terminal velocities. Other factors that determine the terminal velocities are the shape and caliber of the bullets, the direction of the bullets during the movement, and the flight characteristics, such as yaw, precession, tumbling, and nutation. ${ }^{[6,7]}$

Incidentally, the bullet fired upward will not always come back down facing downward. Although the terminal 
velocities are much lower than the muzzle velocity, they still could cause severe injury and death. The bullets' terminal velocity required to penetrate the skin is between 45.1 and $60.0 \mathrm{~m} / \mathrm{s}$ (148 and $197 \mathrm{ft} / \mathrm{s}),{ }^{[6]}$ and bullets traveling at $<60.0 \mathrm{~m} / \mathrm{s}(200 \mathrm{ft} / \mathrm{s})$ can penetrate the skull. ${ }^{[8,9]}$ If kept in mind that the falling bullets have the capability of reaching up to $180 \mathrm{~m} / \mathrm{s}(600 \mathrm{ft} / \mathrm{s}),{ }^{[6,7]}$ the bullets could cause double penetration of the skull not only one pierce.

The incidence and outcome of falling-bullet injuries are challenging and difficult as the minor injury victims will not seek medical care, and the fatalities at the scene will not be reported in the hospital. Moreover, many cases of falling-bullet injuries are reported in the news media and less of them in medical literature. ${ }^{[2]}$ However, their number is rising as firearms and ammunition are more available and widespread, especially in countries where celebratory firing is common. Some falling-bullet causalities are reported in the literature. In 2007, after Iraqi football team won the Asian cup, three people were killed in Baghdad amid widespread gunshots as fans celebrated. ${ }^{[10]}$ From January 2006 to December 2010, 165 patients with a history of stray bullet injuries were admitted in a public sector university hospital in Hyderabad, 13 of which died. ${ }^{[11]}$ Between December 31, 2003, and January 1, 2004, in Puerto Rico, falling bullets from celebratory gunfire of the new year caused 19 injuries and one death. ${ }^{[12]}$ In 1991, celebratory gunfire in Kuwait at the end of the Gulf War II was blamed for 20 deaths. ${ }^{[7]}$ In August 8, 1988, thousands were injured and hundreds died after the Iran-Iraq war ceasefire; almost all of them were injured by falling bullets. ${ }^{[9]}$ Between the years 1985 and 1992, in Los Angeles, doctors treated 118 people for random falling-bullet injuries at King/Drew Medical Center, and 38 of them died. ${ }^{[13]}$

Shooters of falling bullets are predominantly males reported by Wintemute to be $95.9 \%$ and $62.0 \%$ of them were aged 15-34 years. ${ }^{[2]}$ In most of the time, the victims and witnesses are not aware of the gun shooting or noticed how the patient sustained the bullet injury; this will lead to a delay in seeking medical help. Another delay is in the hospital as the first clinical impression is usually away from bullet injury. ${ }^{[11]}$ In one study, $13 \%$ of the cases were diagnosed by radiological images without a clinical suspicion of a bullet injury. ${ }^{[14]}$

In developing and undeveloped countries, a delay also happened in transferring the patient to more specialized hospital. ${ }^{[4]}$ The victims of falling bullets are bystanders and in wide range of age comparing to nonfalling-bullet injuries. Children and elderly are not usually at risk of bullets injury; however, in case of falling bullets, they are. Another salient feature of falling bullets is high percentage of female victims comparing to other nonfalling-bullet injuries although still most of the victims are males.

According to Puerto Rico, 2003 study of celebratory gunfire, out of 19 persons injured from falling bullets, 7 (37\%) were females and $4(21 \%)$ were children comparing to 3 female out of $24(13 \%)$ and no child are injured by nonfalling bullets in the same period of the study. ${ }^{[12]}$ In the Wintemute's study of epidemiology of stray bullet shootings in the united states between March 1, 2008, to February 28, 2009, he found that 142 out of 217 (44\%) of stray bullet victims were females and 99 (31.2\%) were children, while females and children formed only $2 \%$ and $5 \%$ in nonstray bullet injuries, respectively. ${ }^{[3]}$

Another study comparing the sex of bullet victims is Mansor and Bodalal's study of the impact of the method of gunshot injury. They reported that $17.4 \%$ of stray bullet victims are females who are only $2 \%$ and $1.6 \%$ in civilian fighting and war injuries, respectively, in the same period of the study. ${ }^{[15]}$ A higher rate of children injured is reported by Malik et al. who found that $78 \%$ of whom presented with stray bullet injuries during the study period were children. ${ }^{[11]}$ Children were also formed $65.2 \%$ of falling-bullet injuries in one Libyan hospital due to Libyan revolution celebration as documented by Al-Tarshihi and Al-Basheer. ${ }^{[14]}$

In most of the cases, the injury is minor and the bullet lodge in subcutaneous tissue. ${ }^{[2]}$ The majority of the victims are injured by a single bullet ${ }^{[2]}$ although the shooters could be multiple and they used to fire up a large number of bullets. On reviewing the literature, we did not find any documented case with injury by more than single falling bullet.

The mortality rate from falling bullets in general is about $32 \%$ that is significantly higher than nonfalling bullets $2 \%-6 \%$ although the latter's impact is much more potential to kill.. ${ }^{[4,13]}$ This is attributed to the fact that almost no one of falling-bullet victim is wearing antibullet cloths such as helmets. Sometimes, the mortality cases from falling bullets may mimic sudden natural deaths, especially in patients with prior medical history. ${ }^{[16]}$

The head is reported to be the most common site of injury in many studies, ${ }^{[17]}$ such as Puerto Rico's study which revealed $36 \%$ of the cases developed head injury. ${ }^{[12]}$ However, there are studies which rank head injury second to chest, extremities, or both. ${ }^{[2,3,11,14]}$ Double cranium perforation from falling bullets has been reported in many cases. ${ }^{[9]}$

Injuries from falling bullets to the head carry more mortality risk than injury to the other parts of the body and higher surgical intervention rate even in studies that reported less number of head injuries. Al-Tarshihi and 
Al-Basheer reported 50\% mortality among them though they constitute only $8.7 \%$ of falling-bullet victims and all of them required immediate surgical intervention. ${ }^{[14]}$ In Puerto Rico's study, the only single mortality reported was due to head injury. ${ }^{[12]}$ Wani et al. reported two cases of head injuries after falling bullets, one of which was operated and the other one was managed conservatively; the latter died, while the former is surviving with some residual neurological deficit. ${ }^{[4]}$ Cerebral hernia due to increased intracranial pressure is the most common cause of death among falling-bullet head injuries. ${ }^{[17]}$ Ozdemir and Unlü reported a fatality case of a child with falling bullets that penetrate the vertex and coursed through the foramen magnum to stay in spinal canal at the level of T2-3. ${ }^{[17]}$ Furthermore, another child reported to developed penetrating head injury from falling bullet that get migrated later on resulted in sudden deterioration and death. ${ }^{[18]}$

The outcome of head injury from falling bullets depends on age, Glasgow coma score on admission, reactivity of the pupils, the missile course through the brain or base of the patency of basal cisterns skull as well as structures injured through its cerebral course..$^{[9,19,20]}$

\section{Financial support and sponsorship}

Nil.

\section{Conflicts of interest}

There are no conflicts of interest.

\section{Husain A. Abdali, Samer S. Hoz', Luis Rafael Moscote-Salazar 2,3}

Department of Neurosurgery, Salmaniya Medical Complex, Manama, Bahrain, 'Department of Neurosurgery, Neurosurgery Teaching Hospital, Baghdad, Iraq, ${ }^{2}$ Department of Neurosurgery, University of Cartagena, Cartagena de Indias, Cartagena, ${ }^{3}$ Department of Neurosurgery, Cartagena Neurotrauma Research Group, Colombia

Address for correspondence: Dr. Luis Rafael Moscote-Salazar, Department of Neurosurgery, RED LATINO, Organizacion Latinoamericana de Trauma y Cuidado Neurointensivo, Bogota, Colombia. E-mail: mineurocirujano@aol.com

\section{REFERENCES}

1. World Health Organization. International Statistical Classification of Diseases and Related Health Problem. 10 ${ }^{\text {th }}$ Revision. Geneva: World Health Organization; 1992.

2. Ali SA, Tahir SM, Makhdoom A, Shaikh AR, Siddique AJ. Aerial firing and stray bullet injuries: A rising tide. Iran Red Crescent Med J 2015;17:e26179.

3. Wintemute GJ, Claire BE, McHenry V, Wright MA. Epidemiology and clinical aspects of stray bullet shootings in the United States. J Trauma Acute Care Surg 2012;73:215-23.

4. Wani AA, Ramzan AU, Shoib Y, Malik NK, Nizami FA, Dhar A, et al. Stray bullet: An accidental killer during riot control. Surg Neurol Int 2011;2:122.
5. The Falling Bullet: Myths, Legends and Terminal Velocity, The Forensic Outreach Team. Available from: http://www. forensicoutreach.com/library/the -falling- bullet-mythslegends-and-terminal-velocity/. [Last accessed on 2017 Apr 09].

6. Ordog GJ, Wasserberger J, Balasubramanium S. Wound ballistics: Theory and practice. Ann Emerg Med 1984;13:1113-22.

7. Incorvaia AN, Poulos DM, Jones RN, Tschirhart JM. Can a falling bullet be lethal at terminal velocity? Cardiac injury caused by a celebratory bullet. Ann Thorac Surg 2007;83:283-4.

8. Hatcher JS. Hatcher's Notebook. Mechanicsburg, PA: Stackpole Books; 1962.

9. Shuker ST, Sadda R. Craniomaxillofacial falling bullet injuries and management. J Oral Maxillofac Surg 2010;68:1593-601.

10. BBC News. Who, What, Why: How Dangerous is Firing a Gun into the Air? August, 2011. Available from: http://www.bbc.com/ news/magazine-14616491. [Last accessed on 2017 Apr 09].

11. Malik AM, Alkadi A, Talpur KA, Naeem Qureshi J. The incidence, pattern and outcome of stray bullet injuries. A growing challenge for surgeons. Pak J Med Sci 2013;29:1178-81.

12. Centers for Disease Control and Prevention (CDC). New Year's Eve injuries caused by celebratory gunfire - puerto Rico, 2003. MMWR Morb Mortal Wkly Rep 2004;53:1174-5.

13. Ordog GJ, Dornhoffer P, Ackroyd G, Wasserberger J, Bishop M, Shoemaker W, et al. Spent bullets and their injuries: The result of firing weapons into the sky. J Trauma 1994;37:1003-6.

14. Al-Tarshihi MI, Al-Basheer M. The falling bullets: Post-Libyan revolution celebratory stray bullet injuries. Eur J Trauma Emerg Surg 2014;40:83-5.

15. Mansor S, Bodalal Z. The impact of the method of gunshot injury: War injuries vs. stray bullets vs. civilian fighting. J Coll Physicians Surg Pak 2015;25:281-5.

16. Rapkiewicz AV, Shuman MJ, Hutchins KD. Fatal wounds sustained from "falling bullets": Maintaining a high index of suspicion in a forensic setting. J Forensic Sci 2014;59:268-70.

17. Ozdemir M, Unlü A. Gunshot injuries due to celebratory gun shootings. Turk Neurosurg 2009;19:73-6.

18. Hussain M, Bari E. Intracerebral migration of stray bullet leading to sudden and fatal worsening. J Coll Physicians Surg Pak 2011;21:182-3.

19. Aarabi B, Tofighi B, Kufera JA, Hadley J, Ahn ES, Cooper C, et al. Predictors of outcome in civilian gunshot wounds to the head. J Neurosurg 2014;120:1138-46.

20. Gressot LV, Chamoun RB, Patel AJ, Valadka AB, Suki D, Robertson CS, et al. Predictors of outcome in civilians with gunshot wounds to the head upon presentation. J Neurosurg 2014;121:645-52.

This is an open access journal, and articles are distributed under the terms of the Creative Commons Attribution-NonCommercial-ShareAlike 4.0 License, which allows others to remix, tweak, and build upon the work non-commercially, as long as appropriate credit is given and the new creations are licensed under the identical terms.

\begin{tabular}{|c|c|}
\hline \multicolumn{2}{|c|}{ Access this article online } \\
\hline $\begin{array}{l}\text { Quick Response Code: } \\
\text { (a) }\end{array}$ & $\begin{array}{l}\text { Website: } \\
\text { www.ruralneuropractice.com }\end{array}$ \\
\hline aris: & $\begin{array}{l}\text { DOI: } \\
\text { 10.4103/jnrp.jnrp_498_17 }\end{array}$ \\
\hline
\end{tabular}

How to cite this article: Abdali HA, Hoz SS, Moscote-Salazar LR. Cranial gravitational (falling) bullet injuries: Point of view. J Neurosci Rural Pract 2018;9:278-80.

(c) 2018 Journal of Neurosciences in Rural Practice | Published by Wolters Kluwer - Medknow 